\title{
The effects of different actors on urban agriculture: a comparison of the cities of Zaragoza and Valencia in Spain
}

\author{
K. Sakura \\ Department of Engineering, Architectural Course, \\ Shinshu University, Japan
}

\begin{abstract}
Urban agriculture is closely watched because of a currently high interest in organic produce, desires for lush green cities, increased leisure activities, and so on. This study clarifies the locations of urban agricultural lands, why these locations were selected, and the functions of urban agricultural areas in two cities in Spain. The study focuses on the efforts of the Benimaclet Neighborhood Association in Valencia, Spain, and those of the Ebro Ambient Center in Zaragoza, Spain, to address these questions. Valencia's Benimaclet Neighborhood Association is an example of citizen actors, and Zaragoza's Ebro Ambient Center is an example of municipal government actors. This study finds that the locations and functions of urban agriculture differ by type of actor. The study supports research on the implementation of "the suitable place for urban agriculture" when designing sustainable cities of the future.
\end{abstract}

Keywords: urban agriculture, actor, Valencia, Benimaclet Neighborhood Association, Zaragoza, Ebro Ambient Center.

\section{Introduction}

\subsection{Background and purpose}

Urban agriculture has been attracting attention from the perspectives of organic farming, clean and safe agricultural produce, a desire for vibrant green cities, and so on. Scholars in the field of urban planning expect urban agriculture to offer alternative uses for vacant lots. The first purpose of this study is to develop that expectation one step further by clarifying where urban agricultural lands are 
located, why those locations are selected, and the part that urban agricultural areas play in modern cities. Second, this study focuses on two types of urban agricultural land uses according to the type of actor that generates the land use. These two types of actors are governmental, which develop urban agricultural land policy, and residential, which develop urban agricultural lands through citizen activism. The former approach is observed in many European cities. Zaragoza, Spain, one of the target cities of this study, is an advanced case of this type, and it attracts and maintains the attention of other countries as a result. The latter type is a new development in Spanish cities that emerged in the wake of the recent economic crisis. For example, citizens' campaigns created the network of community gardens in Madrid and the network of urban agricultural lands in Alicante. The Benimaclet Neighborhood Association (Association), in Valencia, Spain, the other target city of this study, draws the attention of countries around the world as a pioneer in urban planning. The media cover its activities, and it attracts significant attention [1].

By comparing Zaragoza and Valencia, where different actors developed the urban agricultural lands, this study provides results that will support study on "a suitable location for urban agriculture" when designing sustainable cities of the future.

\subsection{Data and research methods}

The location of urban agricultural land is a key part of this study. Therefore, urban structural development in the study sites is first clarified by examining official documents and urban plans. The next section explains the process of urban agricultural policy or campaign implementation. There is little research published on the development and implementation of urban agricultural land use policy in Zaragoza or on the urban agricultural land campaign in Valencia because these are recent phenomena. For this study, interviews were conducted with Francisco Pellicer Corellano (Chief of the Ebro Ambient Center) and Antonio Pérez Martínez (President of the Benimaclet Neighborhood Association) (Interviews were conducted with Francisco Pellicer Corellano on 6 June 2012, 9 Sep 2015 and 26 Feb 2016. In the case of Antonio Pérez Martínez, they were conducted on 15 Sep 2015 and 29 Feb 2016.). In the last section, the locations and functions of the urban agricultural lands are analyzed by examining urban plans and data from field surveys.

\section{Urban agriculture in Zaragoza}

\subsection{Urban development in Zaragoza}

The city of Zaragoza was founded in about 25 to 12 BCE as a colonial capital of the Roman Empire. The right bank of the middle reaches of the Ebro River was selected as the location of the town because the left bank experienced frequent flood damage. Since ancient times, Zaragoza's abundant water supply has attracted the attention of Aragon, which has a dry climate. Over time, the city 
expanded to the south and west; the Ebro River blocked expansion to the north, and expansion to the east was blocked by the Huerva River. Thus, until the middle of nineteenth century, urban expansion was limited. In the second half of nineteenth century, the city rapidly grew because of modernization.

In 1908, the Spain-France Expo was held in Zaragoza. The municipal government strategically located the venue by transforming the wetlands along the Huerva River, which eased urban expansion toward the southeast. Simultaneously, labor districts for constructing railways (La Almozara district, Delicias district, San Jose district and Torrero-La Paz district) were created on the outskirts of the city because of the city's geographical location in Spain, which is midway between Madrid and Barcelona and between Valencia and Bilbao (Figure 1). During the twentieth century, urbanization in the city and the districts continually progressed. Today, the city and districts have merged and the divisions between them have disappeared.

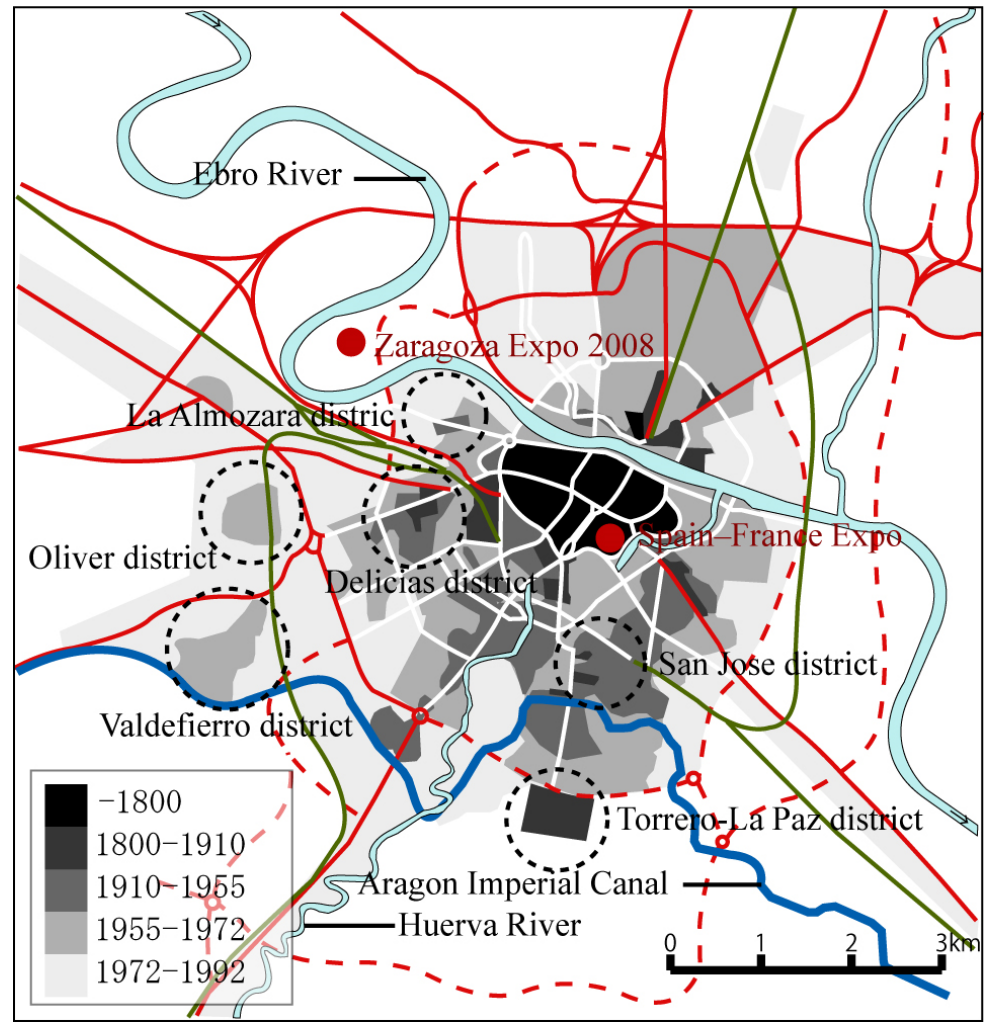

Figure 1: $\quad$ Urban growth of Zaragoza, pre-1800 through 1992. 


\subsection{Urban agricultural policy in Zaragoza}

To date, the Zaragoza Expo 2008 was the city's most important event of the twenty-first century. The municipal government planned the venue and surrounding area of the Expo. The government chose the overhang area of the left bank where flood damage has historically been the worst as the location of the venue because it is a symbol of the city's coexistence with its natural environment. The area was draining because of modernization. The government planned a large park (Parque Metropolitano del Agua) as a protective buffer zone and connected the pavilions with passageways to prepare for possible flooding. For the areas around the Expo, the government employed a strategic urban plan intended to create a ripple effect into the central city. The plan was named the Plan de Acompañamiento de la Expo 2008 (Plan to Accompany Expo 2008) and it comprised public facilities along the river, reorganized existing public spaces, and included a greenbelt project.

The greenbelt project became the basis of Zaragoza's urban agricultural policy. The project influenced the next greenbelt program, which was the Corredor Verde Oliver-Valdefierro (Green Corridor in Oliver-Valdefierro) that connected Oliver and Valdefierro districts by green spaces. That second program influenced the most recent greenbelt program, the El Programa Malla Verde y Azul (Green and Water Network Program). Zaragoza created a vast and diverse green space through this series of greenbelt projects, which includes urban agricultural lands, urban parks, promenades, urban forests, canals, and so on around the perimeter of the city.

The Zaragoza government created the Ebro Ambient Center in 2008 to plan, conduct, and manage the city's urban agricultural policy. Urban agriculture was considered an important element in the Green and Water Network Program. In addition, the following goals were promoted.

1) Develop sufficient understanding of the environment of the rural area

2) Provide healthy and delicious crops at low cost

3) Create healthy and inexpensive enjoyment

4) Create places for social interaction and communication

5) Improve the landscape around the city

6) Improve the poor sanitation near the rundown vacant lots

7) Create pleasurable outdoor nature experiences for families

8) Develop education on the ecosystem, environment, and agriculture

\subsection{Urban agricultural lands in Zaragoza}

The Zaragoza government's policy on urban agricultural land is of three types: Huertos Sociales (social farmland), Huertos Ocios (recreational farmland), and Huertos Asociados (associated farmland). The characteristics of the three types of land are as follows.

Social farmland was created for unemployed, physically challenged, or lowincome retired residents. The idea was to create a space in which users could 
develop social ties through the activity of cultivating crops with others. The locations were chosen for the following reasons. First, they were designated as green space areas in the municipal government's master plan (Plan General de Organización Urbanismo; PGOU). Second, it was public land. Third, the soil was suitable to successful agricultural production. Fourth, the areas were easy to access. The farmland was usually constructed and managed by the municipal government with the support of some private companies and non-profit organizations.

Recreational farmland was intended for all of the citizens. However, users pay basic service fees every month (EUR 50), which limits use to those citizens who can afford the monthly expense. The locations were determined according to the four reasons used to locate the social farmland. The municipal government incurred some expenses from the time the farm opened until 2012. However, since 2013, the Proyectos LIFE + del Ayuntamiento de Zaragoza 2013-2016 (LIFE + Projects of the Zaragoza city government 2013-2016) has been subsidized by the European Commission for its green zone preservation. Because of this support, the number of recreational farmland areas increases every year. Typically, recreational farmland is constructed by the government, then managed by the private enterprise that won the bidding competition to do so.

Associated farmland aims at the overall citizenry. The main feature of this farmland is its goal to convert private land into urban agricultural land through personal or private enterprise. Therefore, associated farmland has no relationship with the municipal government regarding management. However, currently, on the condition that standards are met as stipulated by the government when the urban agricultural lands are developed, the government introduces citizens on the waiting list for recreational farmland to the personal or private enterprises of associated farmland.

\subsection{Locations and functions of urban agricultural lands}

Most of the urban agricultural lands designated by the government are located in the green space area of the master plan, are public land, have soil fertility suitable to successful agricultural production, and are easily accessible to users. The urban agricultural areas also are distributed so that at least one of them is in each of the 15 districts. Moreover, the government planned the locations in accord with the greenbelt program. As a result, areas on the urban periphery that belong to the public that are vast vacant lots are preferentially converted into urban agricultural land (Figure 2). Because they are connected to the greenbelt, users can play sports, have picnics, or bike there as well as cultivate crops. Users can find numerous ways to enjoy the greenbelt in ways that best suit their interests.

Regarding the spatial composition of Zaragoza's urban agricultural lands, most of the large ones comprise agricultural lots, and there is little space in them for users to gather and socialize or for children to play (Figure 3). However, by planning the urban agricultural land in one part of the park or around the greenbelt, the green and public spaces that surround the urban agricultural land compensate for the lack of space within them. 


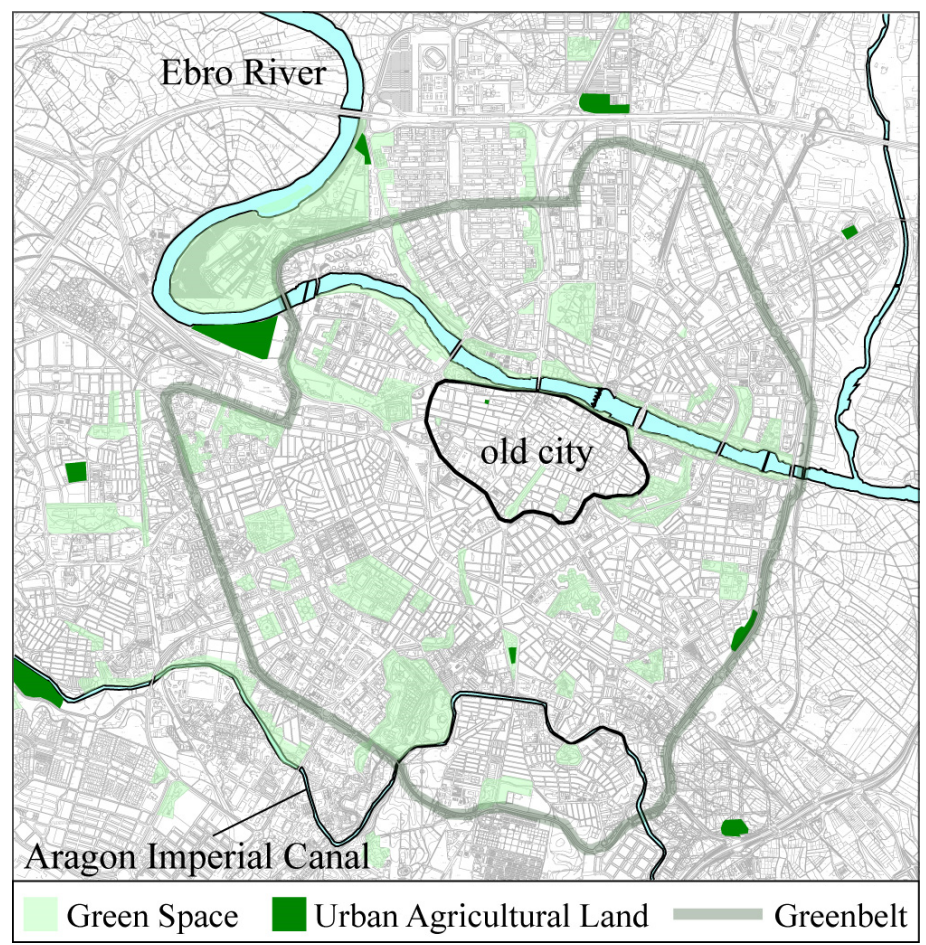

Figure 2: The locations of the three types of urban agricultural land in Zaragoza.

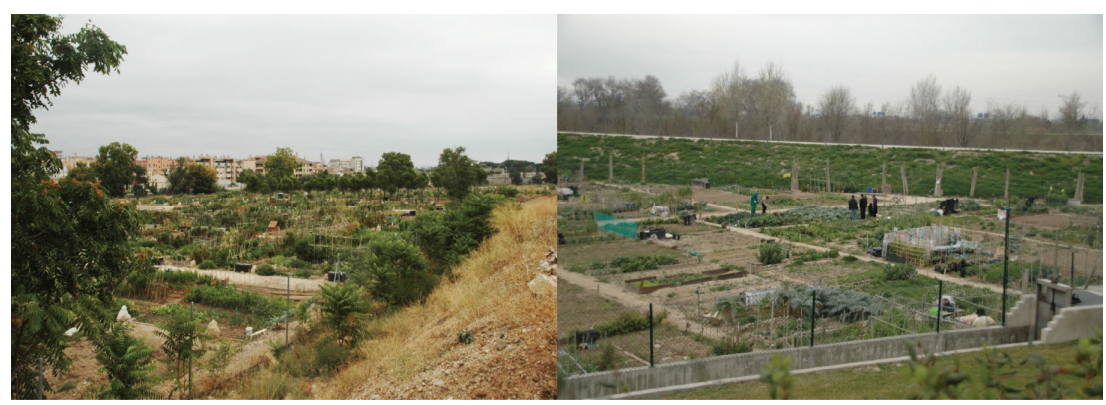

Figure 3: Urban agricultural lands in Zaragoza. 


\section{Urban agriculture in Valencia}

\subsection{Urban development in Valencia}

The city of Valencia was built during the Roman Era near the Turia River as a Roman colonial city. Barcelona, which, like Valencia, is near the Mediterranean coast, was a thriving port city compared to Valencia, which was a successful production base of crops, accomplished by the creation of many irrigation canals that transported water from the Turia River to the fertile farmlands (the "Huerta"). During the Reconquista, recapturing the Huerta was the focus of the invasion of Valencia [2]. Therefore, a strong relationship developed between the city's urban structure, the Huerta, and the topography. Valencia is located in the downstream region of the Turia River and frequent floods have determined the habitable areas of the city since its earliest period. In the beginning, the Mediterranean Sea stretched out east of the city and a mountain range with abundant resources extended to the west. The location of Valencia was perfectly suited to agricultural production.

However, in modern times, the industrial structure changed, the population increased as people migrated from the countryside to the city in the process of modernization, and urban expansion accelerated. Many irrigation canals were filled in and the vast Huerta disappeared. Three expansion plans (Plan del Ensanche) put forth by the central government in 1858, 1884, and 1907 strongly influenced Valencia's urban development. Uniform and grid-shaped blocks were rapidly constructed around the city according to these plans.

Regarding the impacted scale in the city, the Plan Sur (South Plan) is the best known of the plans. The South Plan was developed immediately after a major flood in 1957. The municipal government changed the course of the Turia River toward the south at the outskirts of the city, and then proposed railways and major roads on the dry riverbed of the old Turia River (under the Franco regime). However, during the 1980 s, citizens campaigned to stop construction by taking advantage of the national policies changing to democracy after Franco's death. These actions were successful, the development plans were canceled, and the riverbed was designated as a public green space (Jardin Turia). In addition, urban expansion began to overtake the dry riverbed because the risk of flooding was eliminated. When the seven $\mathrm{km}$ public green space opened to the public, a largescale favorable living environment became possible and the urban area expanded into the entire area (Figure 4).

\subsection{The urban agricultural campaign of the Association}

In Valencia, the municipal government has almost never planned urban agriculture alone. Moreover, Valencia's citizens have more enthusiasm than Zaragoza's citizens for urban agriculture. The Benimaclet district in the northeast part of Valencia has recently attracted considerable attention to its urban agricultural campaign. The Association has continually expanded Valencia's urban 


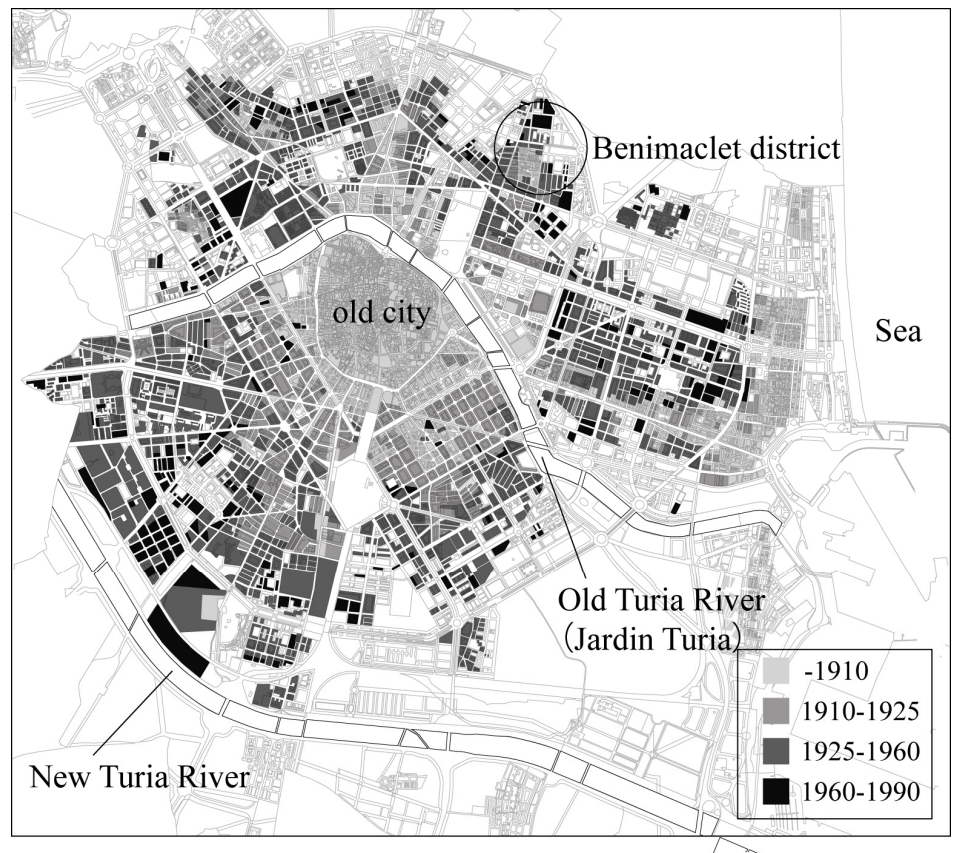

Figure 4: The process of urban expansion in Valencia, pre-1910 through 1990.

agricultural lands since it began campaigning, and it is, therefore, an excellent case by which we can learn how citizens successfully obtain urban agricultural areas.

The history of the campaign is closely linked to the government's urban policy. In 1992, a partial plan for the Benimaclet district aimed to develop the urban area on 25,000 square meters of land. The project was contracted between the municipal government and three private developers (URBEM S. A., EDIVAL, and COBASA S. A.). However, a dispute over the number of social houses arose between the government and the developers, which postponed implementation of the plan several times. Simultaneously, the Lehman Shock (economic crisis) led to the collapse of the bubble economy in Valencia, which forced the developers to relinquish some or all of the land. Ownership of the properties was transferred to Banco Bilbao Vizcaya Argentaria, S.A. (BBVA), one of Spain's leading banks. The development continued to be postponed even after the change in ownership. The breaking up and moving of earth and deposits of trash degraded these lands, which were previously beautiful Huerta.

The Association continued to insist to the government that those degraded lands were having a significant negative impact on the district, which could be alleviated by transforming them into urban agricultural areas. The government rejected the idea, and the Association decided to management these lands by themselves. The Association considered ways to change the abandoned land into the urban agricultural land and brought these ideas to the government, the association of 
Mestalla irrigation canals that managed the irrigation water of the Mestalla area (in Benimaclet district), and the BBVA many times. The government and Mestalla supported the Association, but BBVA did not accept its proposal. The dispute between the Association and the BBVA began at this point and continued for more than one year.

The result of the conflict with the BBVA is that the Association has used the land in question as urban agricultural land since 2012. By transforming the original Huerta into urban agricultural land, the users (mostly residents of Benimaclet district) can use the irrigation canal. Because it is located near the urban area of the district, it is shared recreational space, with a park and a school for teaching agriculture to children, as well as urban agricultural land. The Association sponsors many events, such as a design competition in 2015 regarding the future of the district with respect to the Huerta, irrigation canals, and urban agricultural land [3].

\subsection{Locations and functions of urban agricultural land}

The Association strategically determined the location of the urban agricultural land in the Benimaclet district as follows.

1) Valencia's master plan (PGOU 1988), designates the location as "public space as a general system," meaning that no one can construct buildings in this area during the effective period of the master plan. In the partial plan, the BBVA was not permitted to erect buildings in the area. This made the area easy to use for urban agriculture compared to other areas of the district (Figures 5 and 6).

2) Within the "public space as a general system," the specific land use was near the metropolitan area and irrigation canal.

3) In Valencia, it is crucial to use the irrigation canal to minimize ongoing costs. Furthermore, to use the functional irrigation canal, it is important that the urban agricultural area is situated near the functional Huerta. Therefore, the urban agricultural lands were clustered in the Benimaclet district, which is the nearest district.

Concerning the spatial composition of the urban agricultural land, the majority comprises agricultural lots. However, there is a play area for children, a space for socializing, a small poultry farm, ovens for cooking, and so on. The reason that these diverse functions combine in the urban agricultural land is that the land in Valencia is one large tract because all of the urban agricultural areas were combined at the one location so that all age groups could enjoy the space, which is the direct result of the citizens' campaign. 


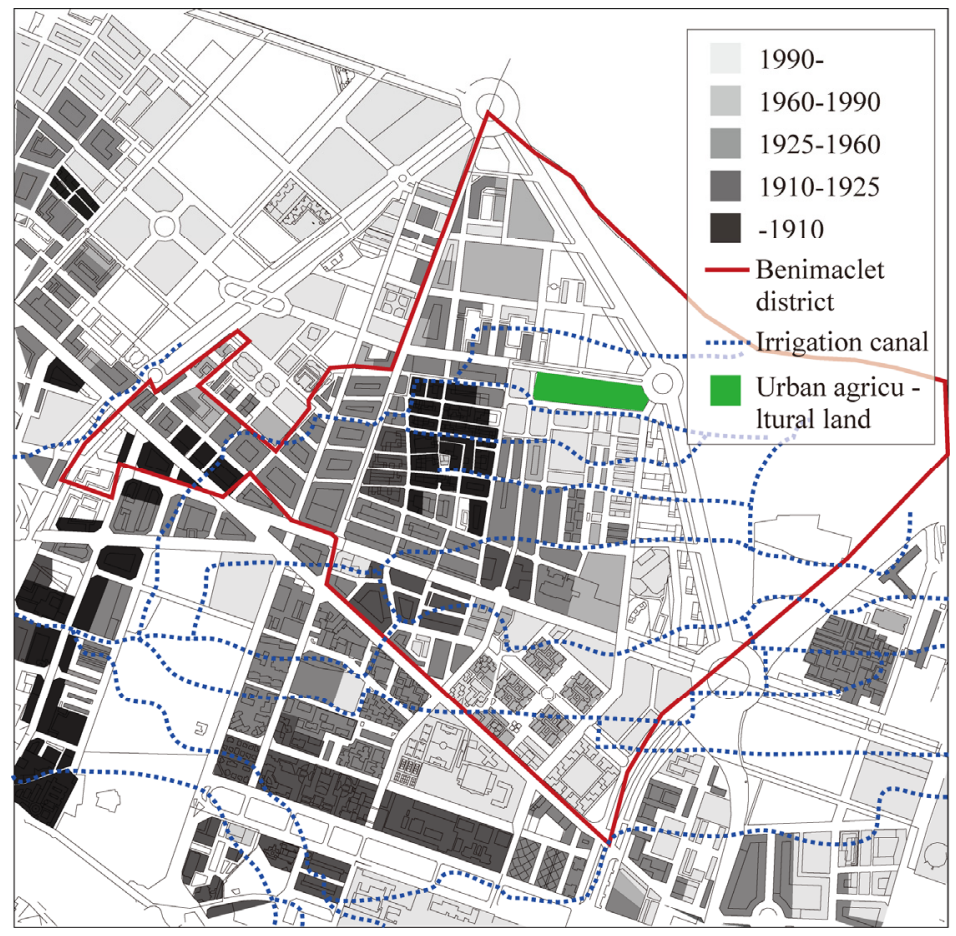

Figure 5: The location of the urban agricultural land in Valencia, pre-1910 through 1990.

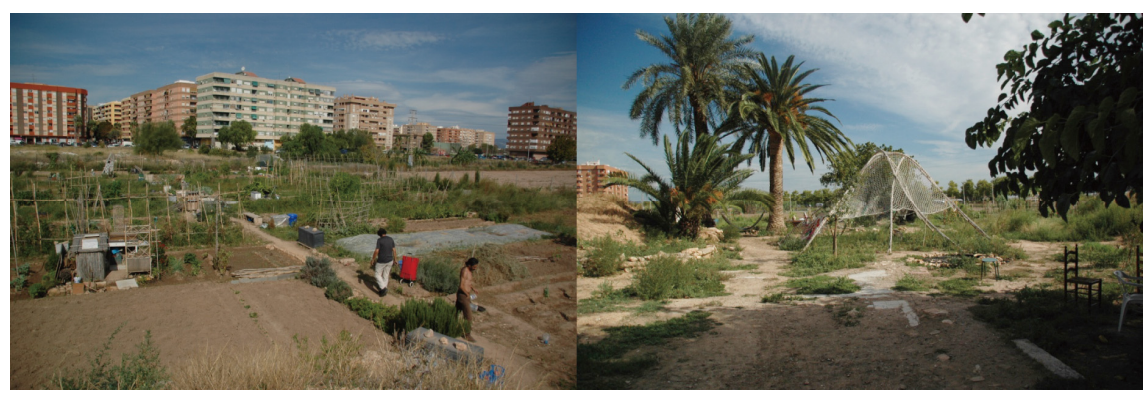

Figure 6: Urban agricultural lands in Valencia.

\section{Conclusion}

The parts played by different actors in the urban agriculture of Zaragoza and Valencia discussed above are as follows. 
1) There is a correlation between the process of urban development and the locations of the urban agricultural lands. In the case of Zaragoza, some labor districts were founded on the outskirts of the city, and the urban area expanded concentrically from the centers of the labor districts and the central city. Design of the urban agricultural lands so that at least one was in each of the 15 districts related to that process of development. In Valencia, the metropolitan area expanded concentrically from the city center and in response to the locations of the canals. To design urban agricultural lands at the margins of the urban area and near the irrigation canals responded to Valencia's particular process of urban development.

2) Different types of actors strategically selected the urban agricultural areas in the two cities. In Zaragoza, the municipal government implemented the urban agricultural policy associated with the greenbelt programs. Therefore, the urban agricultural lands are located near the greenbelt. In Valencia, the Association selected a location that complied with "public space as general system" set forth in Valencia's master plan (PGOU 1988) because of utilizing quickly as the urban agriculture more than the other area in the district.

3) Regarding the spatial designs of the urban agricultural lands, there is a clear difference between the two cities. In Zaragoza, agricultural lots occupy almost all of the land. A few areas have spaces for socializing or education, but they are very small. By planning the urban agricultural land in one part of the park or around the greenbelt, the green and public spaces around the urban agricultural land compensate for their lack of space inside them. In Valencia, the urban agricultural land is not scattered; it is in one location, so there are large agricultural lots plus areas for sports, play, socializing, a small poultry farm, ovens for cooking, and so on for all age groups.

In the future, it will be important to develop urban agriculture based on a strategic plan that includes a variety of actors and types of urban agriculture in the same city. A diversity of urban agriculture would undoubtedly have a positive influence on urban structure.

\section{References}

[1] José Manuel Martín Corvillo, Huertos Urbanos de Benimaclet: La Lucha para Ofrecer Alternativas, Diagonal 2009.12.14 https://www.diagonal periodico.net/global/24888-huertos-urbanos-benimaclet-la-lucha-paraofrecer-alternativas.htm

[2] Enric Guinot Rodríguez, Una Historia de la Huerta de Valencia, In El Patrimonio Hidráulico del Bajo Turia: L'Horta de València, Valencia, Generalitat Valenciana, 2007, p. 74.

[3] Javier Camacho, Fernando Díaz Orueta, Los Huertos Urbanos de Benimaclet: Una Experiencia de Participación de la Ciudad, In Innovación Social y Políticas Urbanas en España, Icaria editorial, s. a., Barcelona, 2015, pp. 224248. 